\title{
İlköğretim Matematik Öğretmen Adaylarının Tasarladıkları Materyallerle Öğretim Programında Yer Alan Değerlerin İlişkilendirilmesi*
}

The Relationship Between the Materials Prepared by

Prospective Primary School Mathematics Teachers with

Values Set Out in the Curriculum*

Dilşat PEKER ÜNAL, Sorumlu Yazar. Dr. Öğr. Üyesi.

Yozgat Bozok Üniversitesi, Eğitim Fakültesi, Eğitim Programları ve Öğretim ABD.

E-mail: dilsat.unal@bozok.edu.tr

ORCID: 0000-0002-1370-4950

Emine Özgür ŞEN, Dr. Öğr. Üyesi.

Yozgat Bozok Üniversitesi, Eğitim Fakültesi, Matematik Eğitimi ABD.

E-mail: senozgur@yahoo.com

ORCID: 0000-0002-8177-0984

ISSN: 1303-880X

e-ISSN: 2667-7504

http://ded.dem.org.tr

Geliş/Received: 01.09.2018

Kabul/Accepted: 30.03 .2019

Makale türü/Article type:

Araştırma/Research
Atıf/Citation: Peker Ünal, D. \& Şen, E.Ö. (2019). İlköğretim matematik öğretmen adaylarının tasarladıkları materyallerle öğretim programında yer alan değerlerin ilişkilendirilmesi. Değerler Eğitimi Dergisi, 17 (37), 77-107.

DOI: $10.34234 /$ ded.456619

* Bu araştırma, ERPA 2018 (International Congresses on Education, İstanbul 28 Haziran - 1 Temmuz 2018) kongresinde sözlü olarak sunulan bildirinin içeriği geliştirilerek ve kısmen değiştirilerek hazırlanmıştır.

* This article is presented 28 June - 1 July 2018 at International Congresses on Education (ERPA 2018) in Istanbul. 
Öz: Bu araştırma ilköğretim matematik öğretmenliği bölümü öğretmen adaylarının matematik dersi öğretim programında yer alan "kök değerler"e yönelik görüşlerini belirlemek ve bu görüşlere dayalı olarak gerçekleştirdikleri bazı uygulamaları ortaya koymak amacıyla yapılmıştır. Bu kapsamda; öğretmen adaylarının "matematik dersinde değerler eğitimi" ve "materyal tasarımı ile değerler eğitimi”"ne yönelik görüşlerini ortaya çıarmak; matematik dersi öğretim programında yer alan değerlere yükledikleri anlamı, en önemli buldukları değeri belirlemek; materyal geliştirme süreci ile değer eğitimi sürecini birlikte yürüttüklerinde ortaya çıkan somut ürünleri incelemek; bu süreçteki duygularını analiz etmek amaçlanmıştır. Araştırmanın çalışma grubunu 56 öğretmen adayı oluşturmaktadır. Araştırma kapsamında nitel araştırma yöntemlerinden doküman incelemesi, görüşme, literatür taraması kullanılmış, verilere içerik analizi uygulanmıştır. Analizler sonunda; öğretmen adaylarının matematik dersi ve matematik materyalleri ile değer kazandırmaya yönelik görüşlerinin olumlu olduğu; yardımseverlik ve öz denetim değerinin anlamını doğru bildikleri ancak saygı değerinin anlamında bazı yanlış bilgilere sahip oldukları; "sevgi" değerinin en önemli değer olduğunu düşündükleri; materyal aracıllğı ile kazandırmak istediği değeri belirleme ve bu değeri materyal ile kazandırma sürecinde ağırlıklı olarak üzüntü, stres, korku, çöküntü, tedirginlik, heyecan, yorgunluk ve hayal kırıklığı gibi olumsuz duyguları hissettikleri ortaya çıkarılmıştır. Çalışmanın sonunda; öğretmen yetiştirme programlarına değerlerin tanınması, öğretilmesi ile ilgili derslerin, etkinliklerin eklenmesi gerektiği önerisi oluşturulmuştur.

Anahtar Kelimeler: Matematik öğretiminde değerler, Öğretim programında değerler, Değerlerin kazandırılması.

$\&$

Abstract: This study aims to determine prospective primary education mathematics teachers' views on the "root values" available in the mathematics curriculum and to reveal some of the practices they actualise on the basis of the views. Within this scope, the study aims to unveil the prospective teachers' views on "values education in mathematics" and on "values education through materials design" and the meaning they attribute to the values available in mathematics curriculum, also to determine the value that they consider the most important, to examine the resultant concrete products when the material development process and the value education process are carried out together, and finally to analyse their feelings in this process. The study group was composed of 56 prospective teachers. Document analysis, interviews and literature review 
were employed; and the data were put to content analysis. Consequently, it was found that the prospective teachers had positive views about instilling values in students through mathematics course and its materials, that they had correct knowledge about the meaning of the values of benevolence and self-control, but that they had some incorrect knowledge about the meaning of the value of respect, and that they considered the value of "love" as the most important value and that they heavily experienced such negative feelings as sadness, stress, fear, depression, uneasiness, tension, tiredness and disappointment in determining the values they wanted students to gain through materials and in the process of applying those materials. The results from this study suggest that values should be introduced into teacher training programmes and that courses and activities about how to teach the values should be included in the programmes.

Keywords: Values in teaching mathematics, Values in the curriculum, Instilling in students' values

\section{Giriş}

Bireylerin davranışlarını şekillendiren, yönlendiren pek çok öge vardır. Bu ögelerden bazıları; geçmişten gelen bilgi ve kültür birikimi, gelenek ve görenekler, bireyin içinde yaşadığ toplumun özellikleri, toplumun kabul ettiği kurallar, kurallara uyulmadığında sergilenen davranışlar ve toplumu bir arada tutan değerlerdir. Sıralanan bu ögelerden değerler; sosyal yaşamı biçimlendirmekte (Dökmen, 2000), farklı özelliklere sahip bireylerin herkes tarafindan kabul edilen kurallara uymasını dolayısıyla ortak paydada buluşmasını sağlamakta, anlaşmayı, birlikte yaşamayı kolaylaştırmakta, bireylere toplumsal yapıda nelerin önemli olduğunu, nelerin tercih edilmesi gerektiğini ve nasıl yaşanması gerektiğini (Akbaş, 2008) bildirmektedir. Değerlerin eğitimi ailede başlamakta, eğitim kurumlarında sürdürülmektedir. Eğitim kurumlarında verilen değerler eğitimi çocukların akademik başarılarını artırmak yanında onların herkes tarafından kabul edilen, etik ve toplum çıkarlarını gözeten davranışlar sergilemelerini sağlamaktadır (Berkowitz, 2011).

Değerlerin kazandırılması eğitim kurumlarında uygulanmakta olan öğretim programları aracılığı ile yerine getirilmektedir. Öğretim programları, öğrenciye kazandırılmak istenen bilgi, beceri ve tutumların dersler kapsamında planlı olarak düzenlenmesidir. Öğretim programlarının içinde, öğretilmesi amaçlanan bilgiler yanında öğrencinin sahip olduğu bilgiyi davranışa dönüştürmesini sağlayacak uygulamalı çalışmalar ve duyuşsal bazı ögeler de yer almaktadır. 
Duyuşsal ögeler ilgi, tutum, güdülenmişlik, kayg1, benlik, kişilik, değer yargıları gibi boyutlardan oluşabilir (Sönmez, 2010, s.90). Günümüzde öğretim programlarının içinde yer alan duyuşsal ögelerle değerler eğitimi gerçekleştirilmektedir.

Yapılan çeşitli araştırmalarda Türkiye'de uygulamakta olan öğretim programlarında değerler eğitimine yer verildiği görülmüştür. Keskin ve Keskin (2009) 1924-2004 yılları arasında ilköğretim birinci kademede uygulanmış olan sosyal bilgiler dersi programını inceledikleri çalı̧̧malarında yoğunlukları farklı olmakla birlikte "barış" değerine yer verildiğini; İdi-Tulumcu ve Tulumcu tarafindan 2015 yılında yapılan çalışmada 1924 ve 2006 yılları arasında uygulanmış olan ilköğretim ikinci kademe Türkçe dersi programlarında "vatansevgisi, demokrasi, düşünce özgürlüğü, ifade özgürlüğü, hak ve özgürlükler, insan hakları, milliyetçilik, Türkçe'yi doğru kullanma, iyimserlik, sevgi, milli kültür” değerlerinin yer aldığını; Yıldırım (2017) 2017 yılında kabul edilen Tarih 9-11, inkılap tarihi ve Atatürkçülük, çağdaş Türk ve Dünya tarihi ve Türk medeniyet tarihi ders programlarını incelediği çalışmasında "adalet, dostluk, dürüstlük, öz denetim, sabır, saygı, sevgi, sorumluluk, vatanseverlik, yardımseverlik" değerlerinin yer aldığını; Karasu-Avcı ve Ketenoğlu-Kayabaşı (2018) 1936-2018 yılları arasında uygulanan hayat bilgisi dersi öğretim programını inceledikleri çalışmalarında programda "sevgi, sayg1, duyarlı1ık, sorumluluk, doğruluk/dürüstlük" değerlerinin yer aldığını yaptıkları çalışmalarla ortaya koymuşlardır. Balcı ve Yelken (2013) öğretmenlerin değer eğitimine en fazla sosyal bilgiler dersinde yer verdikleri daha sonra Türkçe, fen ve teknoloji daha sonra matematik dersinde yer verdikleri sonucuna ulaşmışlardır.

Akbaş (2004) yaptığı bir çalışmada okullarda bilişsel davranışlara ulaşma düzeyinin sürekli kontrol edildiğini ancak duyuşsal davranışların planlı bir şekilde kazandırılmadığını ve değerlendirilmediğini belirtmiş, bu nedenle değerlerin öğrenciler tarafından kazanılma durumunun test edilmesinin gerektiğini belirtmiştir. Bacanlı (2006)'da duyuşsal hedeflere ulaşmanın ve ulaşma durumunun değerlendirilmesinin zor oluşu, bu hedefleri somutlaştırmada güçlük yaşanmaS1, hedeflere ulaşmanın uzun zaman alacağının düşünülmesi, gibi nedenlerle bu kazanımların öğretiminin ihmal edildiğini belirtmiştir. Bu bulgu sınıflarda duyuşsal kazanımların dolayısıyla bazı değerlerin öğretiminin çeşitli gerekçelerle ihmal edildiği sonucunu ortaya çıkarmaktadır.

Değerlerin kazandırılmasında öğretmenlerin değer öğretiminde kullandıkları yaklaşımlar ve sınıfta sergiledikleri davranışlar da büyük önem taşımaktadır. 
Değerlerin öğretiminde kullanılan yaklaşımlar; değerlerin doğrudan öğretimi, değerleri belirginleştirme, değer analizi, bütüncül yaklaşım, örtük program ve karakter eğitimi (Dilmaç, 2011) olarak sıralanmıştır. Öğretmenin kullandığı yaklaşım ne olursa olsun değerler eğitimi sürecinde öğretmenlerin aktif olması gerekmektedir. Diğer bir ifade ile öğretmen çeşitli öğrenme durumları oluşturarak; öğrencileri ikna etmeye çalışarak, kazanılması beklenen değere uygun davranışlar sergilendiğinde pekiştireç vererek; açık uçlu sorularla öğrencilerin kendi değerlerini bulmalarını sağlayacak ortamlar oluşturarak, öğrencileri ikilemde bırakacak durumlar sunarak onların muhakeme etmelerini sağlayarak kazandırmak istediği değerleri öğrencilere verebilecektir. Dilmaç (2002) tarafindan yapılan bir başka çalışmada da değerlerin öğretilmesi aşamasında; öğretmenlerin öğrenciler için iyi bir model olma, sınıf içinde her öğrenciye sorumluluk verme, öğrencilere karar verme, kendi öğrenme sürecini belirleme ve bu süreci izleme firsatı verme davranışlarının sergilenmesi gerektiği belirtilmiştir. Farklı branşta görev yapan 13 İsveçli öğretmenle yapılan bir çalışma, öğretmenlerin, değerleri kavramsallaştırma ve değerler hakkında fikirlerini ifade etme açısından eksiklikleri olduğunu göstermektedir (Thornberg, 2008). Kurtdede-Fidan (2009) öğretmen adayları ile yaptığı çalışmada öğretmen adaylarının değerlere yükledikleri anlamların farklı olduğunu bunun yanında öğretmenlerin değerler öğretimi konusunda öğrencilere model olmada yeterli olmadıkları sonucuna ulaşmıştır. Türkiye ve İsveçli öğretmenlerin değerler eğitimine yönelik görüşlerinin belirlendiği bir başka çalışmada, öğretmenlerin değer ve değerler eğitimini tanımlarken gündelik bir dil kullandıkları, bu alanda profesyonel bilgi eksikliklerinin olduğu sonucuna ulaşılmıştır (Thornberg ve Oğuz, 2013). Elbir ve Bağcı (2013) değerler eğitimi üzerine yapılmış olan yüksek lisans tezlerini inceledikleri çalışmalarında, Türkiye'de değerler eğitiminin yeteri kadar özümsenmediği sonucuna ulaşmışlardır. Ortaokul öğrencilerinin velileri ile yapılan bir çalışmada da velilerin insani, manevi ve milli değerlerin okulda kazandırması gerektiği fikrini benimsedikleri ancak okulun çocuklara değer kazandırma noktasında beklentileri karşılamadığını belirtmişlerdir (Selvitopu, Taş ve Bora, 2015). Görüldüğü gibi yapılan çalışmalar değerler eğitimi konusunun önemsenmediğini, öğretmenlerin değerler eğitimi konusunda model olmada yetersiz olduklarını, velilerin de okullarda verilen değerler kazandırma sürecini yetersiz bulduklarını ortaya koymaktadır. Sıralanan araştırma bulguları öğretmenlerin ve değerler eğitimi konusunun birlikte ele alındığı çalışmaların yapılması gerektiğini ortaya koymaktadır. 


\section{Matematik Dersi ve Değerler}

Matematik dersi sayılarla, şekillerle ilgilenen soyut-teknik bir alan olarak bilinmekte bu nedenle değerler gibi duygulara hitap eden konulardan uzak olduğu düşünülmektedir. Ernest $(2016,189)$ 'de matematiğin nesnel ve değerlerden uzak olduğu yönünde bir algının olduğunu ancak bunun aksini iddia ettiğini, matematiğin epistemolojik, ontolojik, estetik ve etik değerlerle yüklü olduğunu, ayrıca matematiğin açıklık, adalet, demokrasi gibi değerlerle de ilişkili olduğunu belirtmiştir. Durmuş (2010) Bishop ve Seah'tan yaptığı alıntıda (2001) insanların sahip olması gereken değerlerden dinleme, beraber çalışma, açıklık ve iletişimin matematik derslerinde kazandırılabileceğini belirtmiştir. Durmuş (2004) aynı alıntıda öğretmenlerin matematik derslerinde; matematiksel değerlere, matematik eğitimsel değerlere ve genel eğitim değerlerine vurgu yaptığını da belirtmiştir. $\mathrm{Bu}$ alıntıda matematiksel değerlere rasyonalizm-objektivizm, kontrol-ilerleme, gizem-açıklık çiftlerini; matematik eğitimsel değerlere öğretmen ve çalıştığı kurumun belirlediği normlar çerçevesinde öğretilmesi istenen matematiksel bilgi ve işlemleri kazandırmaya yönelik değerleri; genel eğitim değerlerine ise sadece matematikle değil diğer disiplinler aracıllğı ile tüm öğrencilere kazandırılabilecek değerleri örnek olarak vermiştir. Durmuş (2010) Seah'tan (2001) yaptığı alıntıda ders işlerken günlük yaşam dilini kullanan bir öğretmenle doğrudan matematiğin teknik dilini kullanan bir öğretmenin; hesaplamalarda sadece kâğıt-kalem kullanan ve kullandıran bir öğretmenle hesaplamalarda hesap makinası kullanan ve kullandıran bir öğretmenin; hayal gücünü kullanan yaratıcı etkinlikler tasarlayan bir öğretmenin kullanmayan öğretmene göre farklı değerleri öğrencilere yansıttığını belirtmiştir. Dede (2006) matematiğin içinde çeşitli değerleri barındırdığını, bu değerlerin açık değil gizli şekilde öğretildiğini, ders kitaplarında matematiksel değerlerden rasyonellik, kontrol ve açıklığın; matematik eğitimi değerlerinden ise formal bakış, teorik bilgi, işlemsel öğrenme, anlama, erişilebilirlik ve değerlendirme değerlerinin yer aldığını ortaya koymuştur. Görüldüğü gibi matematik dersi de içinde çeşitli değerleri barındırmaktadır.

Dede (2007) yaptığ çalışmada matematik dersinde bilişsel alana yönelik kazanımların öğretiminin daha ön planda tutulduğunu, duyuşsal alanla ilgili öğretim kısmında mesleğe yönelik tutum, inanç, motivasyon konularının ele alınd1ğını ancak değerler öğretiminin ihmal edildiğini belirtmiş̧tir. Bishop (2012)'da matematikte değer eğitimi konusunda yapılan araştırmanın çok az olduğunu, bu konunun ihmal edildiğini belirtmiştir. Bu gerekçeyi Dede (2006) matematik 
dersinin içinde değer barındırmayan bir alan olarak görüldüğü şeklinde açıklamıştır. Tapsir, Pa ve Zamri (2018) matematik dersinde değerler öğretiminin matematiğin duyuşsal yönü olduğunu ancak tartışılmadığını, araştırılmadığını, uygulanmadığını ve ölçülmediğini belirtmişlerdir. Çeşitli çalışmalarla da ortaya çıkarıldığı gibi matematik dersi kazanımları ve değerler eğitimi ile ilgili yapılan araştırmaların sayısı oldukça azdır.

Değerler matematik dersi de dahil olmak üzere pek çok dersin içinde yer almakta, çeşitli yaklaşımlar kullanılarak öğretmenler tarafından öğrencilere kazandırılması gerekmektedir. Öğretmenlerin değerlere yönelik ilgileri, tutumları değerlerin kazandırılmasında büyük önem taşımaktadır. Bu nedenle araştırmada Türkiye'de 2018 yılından itibaren uygulanmakta olan matematik dersi öğretim (5-8. sinıflar) programında yer alan kök değerlerin (adalet, dostluk, dürüstlük, öz denetim, sabır, saygı, sevgi, sorumluluk, vatanseverlik, yardımseverlik) öğretimini gerçekleştirecek olan öğretmen adaylarının değerlere ve değerler eğitimine yönelik görüşlerinin belirlenmesi amaçlanmıştır. Araştırmanın genel amacı öğretmen adaylarının matematik dersinde değerler öğretimi sürecine yönelik çeşitli görüşlerini belirlemek ve öğretmen adaylarının matematik dersinde değerleri öğretmek için ortaya koydukları somut ürünleri tanımaktır. Bu genel amaç kapsamında;

1) Ortaokul matematik eğitimi öğretmen adaylarının "matematik dersinde değerler eğitimi” ve "materyal tasarımı ile değerler eğitimi” konusuna yönelik görüşleri ne yöndedir?

2) Matematik dersi öğretim programında yer alan kök değerlerin alanyazında yer alan tanımı ile bu değerlerin öğretmen adayları tarafindan benimsenen tanımı arasında uyum var midır?

3) Öğretmen adaylarının öğretim teknolojileri ve materyal tasarımı dersi kapsamında kazandırmayı tercih ettikleri değer hangisidir?

4) Öğretmen adayları materyal geliştirme süreci ile değer eğitimi sürecini birlikte yürüttüklerinde hangi somut ürünler ortaya çıkmıştır?

5) Öğretmen adaylarının materyal geliştirme ve değer eğitimi sürecini birlikte yürüttüklerinde hissettikleri duygular nelerdir? 


\section{Yöntem}

\section{Araştırmanın Modeli}

“Gözlem, görüşme ve doküman analizi gibi nitel veri toplama yöntemlerinin kullanıldığı, algıların ve olayların doğal ortamda gerçekçi ve bütüncül bir biçimde ortaya konmasına yönelik nitel bir sürecin izlendiği araştırmalar” nitel araştırma olarak tanımlanmaktadır (Yıldırım ve Şimşek, 2011, s.39). Yapılan araştırmada da olaylar doğal ortamda izlenmiştir. $\mathrm{Bu}$ nedenle nitel araştırma yöntemlerinden yararlanılmıştır. Öğrencilerin matematik dersi öğretim programında yer alan kök değerlere yönelik çeşitli algılarını belirlemek ve bu algılara dayalı olarak hazırladıkları materyalleri değerlendirmek amacıyla görüşme, literatür taraması tekniklerinden yararlanılmış; ulaşılan verilerin analizinde içerik analizi kullanılmıştır.

\section{Çalışma Grubu}

Araştırmanın çalışma grubunu Yozgat Bozok Üniversitesi Eğitim Fakültesi Matematik ve Fen Bilimleri Bölümü İlköğretim Matematik Öğretmenliği bölümü 2. sinıfta öğretim teknolojileri ve materyal tasarımı dersine katılan 56 öğretmen adayı oluşturmaktadır.

\section{Veri Toplama Araçları}

Araştırmanın birinci sorusuna yanıt vermek için öğretmen adaylarının yapılandırılmış görüşme formunu doldurmaları istenmiştir. Yapılandırılmış görüşme formunda;

"Matematik dersinde değerler eğitimi ........... Çünkü..........." ve "Materyal tasarımı ile değerler eğitimi ........... Çünkü..........." cümleleri yer almıştır. Öğretmen adaylarının cümlelerdeki ilk boşluğa "gerçekleştirilebilir/ gerçekleştirilemez" sözcüklerinden birisini yazmaları ve "Çünkü" ile başlayan boşluğa neden bu şekilde düşündüklerini açıklamaları istenmiştir. Araştırma konusunda bilgiye sahip aynı zamanda nitel araştırma konusunda uzman bir araştırmacıdan hazırlanan görüşme formu hakkında görüş alınmıştır. Uzman ile araştırmanın amacı ve veri toplama teknikleri hakkında görüşülmüştür. Uzman araştırmacı yapılandırılmış görüşme formunun anlaşılır olduğunu ve amaca hizmet edebileceğini belirtmiştir. Yapılandırılmış görüşme formunun doldurulma- 
S1 çalışması öğretim teknolojileri ve materyal tasarımı dersinin ilk haftalarında gerçekleştirilmiştir.

Araştırmanın ikinci sorusuna yanıt vermek için matematik dersi öğretim programında yer alan kök değerlerin (adalet, dürüstlük, dostluk, öz denetim, sabır, sayg1, sevgi, sorumluluk, vatanseverlik ve yardımseverlik) öğretmen adayları tarafından tanımlanması istenmiştir. Bu çalışma da öğretim teknolojileri ve materyal tasarımı dersinin ilk haftalarında gerçekleştirilmiştir.

Araştırmanın diğer sorularına yanıt vermek için öğretmen adaylarının öğretim teknolojileri ve materyal tasarımı dersi boyunca (14 hafta) günlük tutmaları istenmiştir. Öğretmen adaylarının günlük tutarken kullanacakları defter araştırmacılar tarafından öğrencilere dağıtılmış, öğrencilerin günlüklere tarihi, ilgili tarihte yaptıkları çalışmayı, çalışma sırasında hangi zorluklarla karşılaştıklarını, kimlerden, nasıl yardım aldıklarını, nasıl bir ürün tasarladıklarını ve gerçekleştirdiklerini, bu süreçteki duygularını, düşüncelerini yazmaları gerektiği belirtilmiştir.

\section{Verilerin Toplanması ve Analizi}

Araştırma verileri sorumlu yazar tarafinda uygulanan öğretim teknolojileri ve materyal tasarımı dersi kapsamında toplanmıştır. Araştırmanın birinci sorusuna yanıt vermek için öğretmen adayları tarafından doldurulan yapılandırılmış görüşme formunda yer alan yanıtlara betimsel analiz yapılmıştır. Betimsel analizde verilen yanıtlar "Matematik dersi kapsamında değer eğitimi yapılabilir", "Matematik dersi kapsamında değer eğitimi yapılamaz", "Matematik dersi kapsamında değer eğitimi bazı kazanımlarla yapılabilir, bazı kazanımlarla yapılamaz" temaları altında sınıflandırılmış ve sayısal hale dönüştürülmüştür.

Araştırmanın ikinci sorusuna yanıt vermek için matematik dersi 5-8. sınıf öğretim programında yer alan kök değerlerin (adalet, dürüstlük, dostluk, öz denetim, sabır, saygı, sevgi, sorumluluk, vatanseverlik ve yardımseverlik) tanımları, Türk Dil Kurumu Türkçe Sözlük, Dil Derneği Türkçe Sözlük ve Eğitim ve Eğitim Bilimleri Sözlüklerinden ayrı ayrı bulunmuş, her bir değer için üç tanıma ulaşılmıştır. Bu tanımlardaki ortak kavramlar belirlenmiş, bu kavramlar ölçüt kabul edilerek öğrenci tanımlarının bu ölçüte uyma durumu değerlendirilmiştir. Oluşturulan ortak kavramlar hakkında Türk Dili ve Edebiyatı uzmanından görüş alınmıştır. Değerlendirme çalışmasında araştırmacılar tarafından hazırlanan bir rubrikten yararlanılmıştır. Rubrik oluştururken bir ölçme değerlendirme uzmanından görüş alınmış, öğrencilerin yazdığı tanımın "belirlenen ölçütlere 
uyma durumu yetersiz" ise sıfır puan; "belirlenen ölçütlere uyma durumu geliştirilmeli" ise bir puan; "belirlenen ölçütlere uyma durumu kabul edilebilir" ise iki puan verilmiştir. Böylece öğrencilerin yazdığı her bir tanıma puan verilmiştir. Örneğin "yardımseverlik" değeri; sözlüklerde "hayırseverlik, iyilikseverlik, yardımsever olma durumu" olarak tanımlanmıştır. Öğrencilerin yazdıkları tanımlardan; "Elimizden geldiğince zorda kalana hiçbir karş1lık beklemeden yardımcı olmaktır.", "Karşlıksız iyilik yapmaktır.", "Çevresindeki zor durumda kalmış kişilere yardım etme işidir." kabul edilebilir düzeyde bulunmuş ve 2 puan almıştır. "Bir tarafın diğer tarafın hayatını kolaylaştırma isteğì", "Bir kişiyi zor durumda gördüğümüzde ona yol göstermek" tanımları geliştirilebilir düzeyde bulunmuş ve 1 puan almıştır. Bunun yanında "Bence sadece din için değil sırf insan olduğumuz için yani insani değerden dolayı yapılması gerekiyor”, "İnsanların birbirlerine daima ihtiyacı vardır. İnsanlar gücü yetebildiğince birbirine yardım etmelidir. Yardım karşısındaki insanın mutluluğu yardım yapanı da mutlu eder." tanımları yetersiz bulunarak sıfır puan almıştır.

Benzer şekilde "öz denetim” sözlüklerde "İnsanın kendi davranışlarına istemi ya da aklı ile yön vermesi", "Daha önemli bir amaca ulaşabilmek için kişinin tepkilerini, davranışlarını ya da başka bir amaca yönelme eğilimini denetleyip, kısıtlaması, otokontrol” olarak tanımlanmıştır. Öğrenciler tarafından yapılan tanımlarda; "İnsanların kendilerini kontrol edebilmeleri, davranışlarını düzenleyebilmeleridir”, "Kendini ve yaptıklarını düzenlemek, amaca göre oluşturmaktır" ifadeleri kabul edilebilir düzeyde bulunmuş ve 2 puan almıştır. "Kendi davranışlarını olumlu ya da olumsuz yönde sorgulayabilmesidir.", "Kişinin vicdanını sorgulamasıdır" tanımları geliştirilebilir düzeyde bulunmuş ve 1 puan almıştır. Bunun yanında "Kendimizi olmak istediğimiz kişiye göre eğitmek", "Öz denetim bende yok, olanları tebrik ediyorum." tanımları yetersiz bulunmuş ve sıfır puan almıştır.

"Saygı" değeri sözlüklerde "Üstünlük, nitelik, yaş, vb. bakımlardan başkalarına ya da başka nesnelere (örgüt, felsefe, program, kurum ya da yaşama düzeni, vb.) duyulan sevgi ile çekinme karşılığı bir bağlılık duygusu"; "Değeri, üstünlüğü, yaşlılı̆̆1, yararlığı, kutsallığ dolayısıyla bir kimseye, bir şeye karş1 dikkatli, özenli, ölçülü davranmaya sebep olan sevgi duygusu, hürmet, ihtiram", "Başkalarını rahatsız etmekten çekinme duygusu" olarak tanımlanmıştır. Bu tanımlarda "özne: başkalarına ya da nesnelere"; "yüklem: duygu" olarak belirlenmiş ve öğrencilerin tanımları özne, nesne ve yükleme uygunluğuna göre değerlendirilmiştir. Örneğin; "Karşıdaki kişiye değer ve sevgi verdiğinden olu- 
şan değer", "Bir kişiye ya da topluma ya da nesneye sevgiden dolayı gösterilen hoşgörü” tanımları kabul edilebilir bulunmuş ve 2 puan almıştır. Ancak "Karş1mızdaki durumu, olayı, bireyi yargılamamak, eleştirmemek", "Her kim olursa olsun, büyük küçük demeden, düşmanımız bile olsa nerede nasıl konuşacağımız1, hareket edeceğimizi bilmek", "İnsanların birbiri ile geçinebilmesi” tanımları yetersiz bulunarak sıfır puan almıştır.

İkinci aşamada her bir değerin 56 öğrenciden aldığı puanlar toplanmıştır. Bir değerin bütün öğrencilerden 2 puan almas1 $(56 \times 2=128)$ o değerin tanımının bütün öğrenciler tarafından bilindiğini göstermektedir. Bir değerin aldığı toplam puan; 87-128 arasında ise öğrenciler tarafından yapılan tanımın gerçek tanıma "tam uygun", 44-86 arasında ise "geliştirilmesi gerektiği", 0-43 arasında ise değerin tanımının "uyumsuz" olduğu kabul edilmiştir.

Araştırmanın üçüncü sorusuna yanıt vermek için öğretmen adaylarının öğretim teknolojileri ve materyal tasarımı dersinde materyal geliştirme sürecinde kazandırmayı tercih ettikleri değerler belirlenmiştir. Değer belirleme sürecinde öğrencilerin günlüklerinden yararlanılmış, her bir öğrencinin kendisine verilen kazanımla birlikte öğretmeyi tercih ettiği değer belirlenmiş, tercih edilen değerlerin frekansı hesaplanmıştır.

Araştırmanın dördüncü sorusuna yanıt vermek için öğretmen adaylarının öğretim teknolojileri ve materyal tasarımı dersi kapsamında ortaya koydukları somut çalışmalar incelenmiştir. Bu süreçte;

1) Öğretim teknolojileri ve materyal tasarımı dersinde ilk 5 hafta dersin teorik kısımları öğretim üyesi tarafından öğretmen adaylarına anlatılmış, örnekler gösterilmiş ve anlatılan uygulamaların sınıfta küçük grup çalışmaları ile gerçekleştirilmesi istenmiştir. Öğretmen adayları tarafından gerçekleştirilen çalışmalar sınıfta değerlendirilmiştir.

2) 5-8. sınıf matematik dersi öğretim programı öğretmen adayları ile birlikte incelenmiş, programda kazandırılması gereken değerler vurgulanmış, bu değerlerin kazanımlarla bütünleştirilerek öğretiminin yapılması gerektiği belirtilmiştir.

3) Öğretim programının incelemesi tamamlandıktan sonra öğretim üyesi tarafindan öğretim programında yer alan kazanımlar öğretmen adaylarına dağıtılmış ve bu kazanımlara uygun materyal geliştirmeleri gerektiği belirtilmiştir. Bu çalışmada öğretmen adaylarının programda yer alan değerlerden birisini seçmeleri ve bu değerin öğretimi ile materyal geliştirme sürecini 
birlikte tasarlamaları gerektiği bilgisi verilmiştir. Aynı gün her bir öğretmen adayının sunum yapacağı tarih de belirtilmiştir.

4) Kazanımların ve sunum tarihlerinin belirlendiği gün, günlükler dağıtılmış, öğretmen adaylarının kazanımlarını öğrendikleri dakikadan başlayarak duyguların1-düşüncelerini, hangi değeri hangi gerekçe ile seçtiklerini ve kazanım-değer ilişkisini nasıl kurduklarını kaydetmeleri istenmiştir.

5) Sunum tarihi gelen öğretmen adayının, sınıfta materyalini kullanarak, kazanımın bilgisini aktarması ve değerini kazandırması istenmiştir. Sunumunu yapan öğrencinin günlüğü öğrenciden teslim alınmıştır.

Araştırmanın beşinci sorusuna yanıt vermek için öğretmen adaylarının tuttukları günlüklerin analizi yapılmıştır. Öğretmen adaylarının kazanımlarını öğrendikleri günden sunumlarını yapıncaya kadar geçen sürede hissettikleri duygular belirlenmiş, duygular olumlu ve olumsuz olarak iki kategoriye ayrılmıştır.

\section{Bulgular}

1) Matematik dersi öğretmen adaylarının "matematik dersinde değerler eğitimi" ve "materyal tasarımı ile değerler eğitimi" konusuna yönelik görüşlerini belirlemek için yapılan analiz sonucunda ulaşılan bulgular aşağıda sıralanmıştır.

Matematik dersi öğretmen adaylarının 38'i "matematik dersinde değerler eğitimi”nin gerçekleştirilebileceğini, 1'i gerçekleştirilmeyeceğini, 17'si ise matematik dersindeki bazı kazanımlarla değerler eğitimi yapılabileceğini, bazı kazanımlarla yapılamayacağını belirtmiştir. Bu veriler araştırmaya katılan matematik dersi öğretmen adaylarının "matematik dersinde değerler eğitimi”ne yönelik görüşlerinin "yapılabilir" yönünde olduğunu göstermektedir. Çalışma grubunda yer alan öğretmen adaylarının \%68'i matematik dersi kapsamında değerler eğitiminin yapılabileceğini düşünmektedir. Matematik dersinde değerler eğitiminin gerçekleştirilebileceğini belirten öğretmen adayları görüşlerini aşağıdaki cümlelerle ifade etmişlerdir;

"Matematik dersi öğretmen adayı olarak bu değerlerin matematik dersi kapsaminda gerçekleştirilebileceğini düşünüyorum. Çünkü okullar öğrencileri hayata hazırlar ve bu değerlerin hepsi hayatın aslında ta kendisidir. Biz öğretmenler olarak verilen kazanımlar aracılığı ile öğrencilerimize adaleti, öz denetimi, sabrı, sayglyı, sevgiyi, yardımseverliği, öğretebiliriz. Örneğin oran-orantı ile eşitliği, adaleti ögretebiliriz. Pasta dilimi, pastadan pay alma verme konusunda "eşit şekilde paylaşmak için Ayşe'ye kaç dilim pasta vermeliyim?” sorusu ile 
yardımseverlik, sevgi, saygı değerlerini kazandırabiliriz. Ya da çıkarma işleminde komşudan onluk almanın yardımseverlik ögretiminde yararlı olacağını düşünüyorum. Öz denetim değerini kazandırmak için öğrencinin yaptı̆̆ işlemi sorgulaması ve sonucu düşünmesi sağlanabilir."

"Bu değerler sadece Türkçe, sosyal bilgiler ya da din kültürü dersinin konusu değil. Bu değerler tüm insanlı̆̆ ilgilendiren ortak değerlerdir. Biz de derslerde sadece matematik anlatıp bırakmamallyız. Gerektiğinde ahlak, edep, insanllk gibi temel değerleri vermeliyiz. Önce eğitim sonra öğretim yapmalıyız."

"Bir problem metninde paralarımızı ögretirken "Galiba bu ay 200 TL fazla harcadım, diğer ay açı̆̆ımı daha fazla çalışarak kapatabilirim” diyen bir babanın durumu verilebilir ve bu yola hem paralarımız ögretilir hem de öz denetim değeri verilmiş olur."

"Okul sadece ders anlatmak için değildir. Öğrenciler dersten sıkıldığında bu değerleri hikâye aracılı̆̆ ile onlara aktarabilirim."

Matematik dersinde değerler eğitimi yapılamayacağını düşünen bir öğretmen aday1 görüşünü; "Bu ders kapsamında tam olarak oturtulmuş bir değer eğitimi sürecinin olacağına inanmıyorum. Eğitimde hangi ders kapsamında olursa olsun insan yetiştirildiğini, matematik dersinin temel ögesi olan sayllarla bu değerlerin kazandırılmayacă̆ını, bütün öğretmenlerin derse giriş-çıkışlarda, sinifta tutum sergilerken, ortak etkinlikler yapılırken, öğretmen-öğrenci arasinda birebir sohbet gerçekleştiğinde bu değerlerin kazandırılacağını düşünüyorum. Sadece sayılarla uğraşırken bu kazanımın sağlanamayacă̆ını düşünüyorum. Arada iletişim olan her ders kapsamında değer kazandirllabilir ama matematikte zor. Bunun yanında matematikteki kazanımlar bilişsel temelli ama değerler duyuşsal kazanımlar. Bu ikisinin aynı anda verilmesinin zor olacağına inanıyorum. Aile desteği olmadan değer kazandırma yapılamaz." cümleleri ile ifade etmiştir.

Matematik dersinde değerler eğitiminin bazı kazanımlarla yapılabileceğini, bazıları ile yapılamayacağını düşünen bir öğretmen adayının bu konudaki görüşünü; "Karşımızdakiler çocuk, her söylediğimizi can kulağı ile dinliyorlar. Bizim bu çocuklarla geçireceğimiz $40 \mathrm{dk}$. süremiz var. Derse girişte, sonunda ya da ders sirasında bu değerlere değinebiliriz ancak bazı değerler var ki, öz denetim gibi bunların kazanımı aileden başlar, biz pek bir şey yapamayız." cümleleri ile ifade etmiştir.

Görüldüğü gibi öğretmen adaylarının matematik dersinde değerler eğitimi konusundaki görüşleri olumludur. 
"Matematik kazanımlarına uygun materyaller aracıllğ̆ ile değer eğitimi”" gerçekleştirilmesine yönelik görüşler analiz edildiğinde öğretmen adaylarının 37'si "matematik kazanımlarına uygun materyaller aracılı̆̆ 1 ile değer eğitimi” yapılabileceğini, 1'i yapılamayacağını, 12'si ise bazı materyallerle değer eğitimi yapılabileceğini, bazı materyallerle yapılamayacağını belirtmiş̧tir.

Matematik kazanımlarına uygun materyallerle değer eğitimi yapılabilir şeklinde görüşe sahip olan öğretmen adaylarından bazılarının görüşleri aşağıdaki gibidir:

"Bilgisayarda matematikte bölme ögretiyoruz diyelim. Birbiri ile elma paylaşan çocukların videosunu izletiyoruz. A kişisinin 10 elmast var, diğer arkadaşına kaç elma verirse elma sayıları eşit olur diyoruz. Böyle bir video ile öğrencilere paylaşmayl, yardımlaşmayı öğretebiliriz."

"Yapılan materyaller görsel ve somut olduğu için değerlerin aktarımının daha kolay olacă̆ını düşünüyorum."

"Materyal tasarımında bu değerleri konunun üstüne ekleyerek matematikle birlikte verebiliriz. Örneğin bayrağımızın hilal ve yıldızının geometrik olarak incelenmesi ile vatanseverlik değeri verilebilir.”

Matematik kazanımlarına uygun materyaller aracılığı ile değer eğitimi yapılamayacağını düşünen bir öğretmen adayının görüşü: "Değerler soyut ve manevi, ögrenciler bunların ne olduğunu biliyor ancak benim gibi tanımlamada zorluk çekiyor. Bunun sebebi soyut olmaları. Matematik de soyut bir kavram. Materyal tasarımı ile soyut iki kavramın kazandırılması zor olabilir.” şeklinde görüşünü açıklamıştır. Görüldüğü gibi öğretmen adaylarının materyal tasarımı ile değerler eğitimi konusundaki görüşleri olumludur.

2) İkinci araştırma sorusunda matematik dersi öğretim programında yer alan değerlerin alanyazında yer alan tanımı ile bu değerlerin öğretmen adayları tarafından benimsenen tanımı arasındaki uyum belirlenmeye çalışılmışı̧ı. $\mathrm{Bu}$ süreçte bir değerin alabileceği en yüksek puan belirlenmiş, değerin öğretmen adaylarından aldığı en yüksek puan hesaplanmış ve iki puan birlikte değerlendirilmiştir. Verilerin analizinden sonra aşağıdaki sonuçlara ulaşılmıştır: 


\begin{tabular}{llll}
\hline \multicolumn{2}{l}{ Tablo 1: } & Değer Tanımlarının Uyumlarının Belirlenmesi & \\
\hline Sıra no & Değerin adı & Değerin aldığı puan/alabileceği en yüksek puan & Tanımların uyumu \\
\hline 1 & Dürüstlük & $42 / 128$ & Uyumsuz \\
\hline 2 & Dostluk & $27 / 128$ & Uyumsuz \\
\hline 3 & Adalet & $33 / 128$ & Uyumsuz \\
\hline 4 & Öz denetim & $72 / 128$ & Geliştirilmesi gerek \\
\hline 5 & Sabı & $23 / 128$ & Uyumsuz \\
\hline 6 & Saygı & $4 / 128$ & Uyumsuz \\
\hline 7 & Sevgi & $16 / 128$ & Uyumsuz \\
\hline 8 & Sorumluluk & $32 / 128$ & Uyumsuz \\
\hline 9 & Vatanseverlik & $50 / 128$ & Uyumsuz \\
\hline 10 & Yardımseverlik & $77 / 128$ & Geliştirilmesi gerek \\
\hline
\end{tabular}

Görüldüğü gibi matematik eğitimi öğretmen adayları tarafından yapılan 10 değer tanımının 8'i sözlüklerde belirlenen tanımlar ile uyumsuzdur. Diğer bir ifade ile değerleri öğrencilere kazandıracak matematik dersi öğretmen adaylarının değerlere yüklediği anlam yetersizdir. Öğrencilerin anlamını en iyi bildikleri değer "yardımseverlik”tir. Bu değer toplam 128 puan üzerinden 77 puan almıştır. Bu puan, değerin anlamının öğretmen adayları tarafından iyi bilinmediğini ancak diğer değerlere oranla daha iyi bilindiğini göstermektedir. Benzer şekilde yapılan bir puanlama ile öğrenciler tarafından anlamı en iyi bilinen ikinci değerin "öz denetim" olduğu görülmüştür. Bu değerin anlamı da çok yeterli olmamakla birlikte diğer değerlere göre daha iyi olduğu (72/128) görülmektedir. Yukarıdaki tabloda en düşük puanı (4/128) "saygı" değerinin aldığ 1 görülmektedir.

3) Araştırmanın üçüncü sorusuna yanıt vermek için öğretmen adaylarının öğretim teknolojileri ve materyal tasarımı dersinde kazandırmayı tercih ettikleri değer belirlenmiştir.

Öğretmen adaylarının hazırladıkları materyali sınıfta sunarken kazandırmayı hedefledikleri değerlerin dağılımı aşağıdaki tabloda gösterilmiştir:

\begin{tabular}{ll}
\hline Tablo 2: Öğretmen Adayları Tarafından Öğretimi Tercih Edilen Değer \\
\hline Değer & Tercih edilme sayısı \\
\hline Dürüstlük & 4 \\
\hline Dostluk & 1 \\
\hline Adalet & 4 \\
\hline Öz denetim & 1 \\
\hline Sabır & 1 \\
\hline Sayg1 & 4 \\
\hline Sevgi & 12 \\
\hline Sorumluluk & 10 \\
\hline Vatanseverlik & 11 \\
\hline Yardımseverlik & 8 \\
\hline Toplam & $\mathbf{5 6}$
\end{tabular}


Tablo 2'de görüldüğü gibi öğretmen adaylarının kazandırmayı en çok tercih ettikleri değer "sevgi"dir. Sevgi değerini "vatanseverlik" ve "sorumluluk" izlemektedir. Sevgi değerini tercih eden öğretmen adaylarının bu değeri tercih etme gerekçelerini;

"Sevginin çok önemli olduğunu ama insanların bu değerin önemini kaybettiklerini düşünüyorum."

"Kazanımıma en uygun değer sevgi, bu değerle ilgili daha çok problem durumu oluşturabildim."

"Sevgiyi çocuklara anlatmak yaşatmak çok önemli, sevgi başarının ve pek çok değerin temeli. Öğretmenler için de sevgi olmazsa olmaz."

"Sevgi olmadan insan ilişkileri çok zayıf olur ve öğrenciler arasindaki ilişki zayıfladiğı için öğrencilerin aileleri ve çevreleri ile tutumları da olumsuz olur." olarak açıklamışlardır.

"Vatanseverlik" değerini tercih eden öğretmen adayları bu değeri seçme gerekçelerini;

"Ülkemizde terör olayları çok yoğun yaşanıyor. Çocuklar babasız kalıyor bu duygu çok önemli bence, ayrıca abim Diyarbakır'da polis ne zaman televizyonda Diyarbakır adını duysak geriliyoruz. Başkaları bu duyguyu yaşamasın diye vatan sevgisine önem vermek istiyorum."

"Küçük yaşta öğrencilere bu bilincin kazandırılması gerekiyor. Geçmişini bilmeyen geleceğini de bilemez. Mustafa Kemal Atatürk yolunda ilerleyen, vatanını milletini seven bireyler olmalı benim öğrencilerim."

"Bu zamanda en çok ihtiyacımız olan şey bu kavram" olarak açıklamışlardır.

Görüldüğü gibi çalışma grubunda olan öğretmen adaylarının sırasıyla "sevgi" ve vatanseverlik" değerini önemsedikleri ortaya çıkmıştır.

4) "Öğretmen adaylarının materyal geliştirme süreci ile değer eğitimini bütünleştirmeleri sonucunda hangi somut ürünler ortaya çıkmıştır?" sorusuna yanıt vermek için öğretmen adayları tarafından kazanımlara uygun olarak hazırlanan ve içinde değer kazandırma süreci bulunan bazı çalışmalar örnek olarak sunulmuştur. Bu araştırma sorusunda öğretmen adaylarının etkinlik geliştirme süreci ile değer eğitimi sürecini birlikte yürüttüklerinde ortaya ç1karacakları somut ürünleri görmek/tanımak amaçlandığı için değerlendirme yapılmamıştır.

Kazanım: M.6.3.4.2.Verilen bir hacim ölçüsüne sahip farklı dikdörtgenler prizmalarını birim küplerle oluşturur, hacmin taban alanı ile yüksekliğin çarpı$\mathrm{m}$ olduğunu gerekçesiyle açıklar. 


\section{Değer: Dostluk}

Öğretmen adayı 56 kişi olan sınıf mevcudunu 7 kişilik gruplara ayırdı, her gruba hazır olarak yapılıp satılan birim küpler verdi ve bu küplerden ayrıt uzunlukları farklı olan dikdörtgenler prizması yapmalarını istedi. Öğrencilerin yaptıkları dikdörtgenler prizmasının üzerine saygı, sevgi, hoşgörü yazmalarını istedi. Sonra kendisi asetatlardan bir dikdörtgenler prizması yapıp adına "dostluk prizması" dedi. Bu dostluk prizmasını eliyle sallayıp ne kadar dayanıksız olduğunu gösterip "Çıkar ilişkisinin olduğu, sevgi, saygı ve hoşgörünün olmadığı arkadaşlıkların da bu şekilde zayıf olacağını" vurguladı. Daha sonra dikdörtgenler prizmasının içine öğrencilere verdiği ve ayrıt uzunlukları farklı olan dikdörtgenler prizmasından yapılan birim küpleri yerleştirdi. Yerleştirirken de "bu saygı", "bu sevgi”, "bu hoşgörü” dedi ve prizmayı birim küplerle doldurunca prizmanın daha sağlam olduğunu vurguladı, dostluğun da saygı, sevgi ve hoşgörü ile daha sağlam olacağını belirtti. Elindeki içi dolu prizma aracılığı ile hacim ve yükseklik bilgisini verdi.

Kazanım: M.5.1.2.6. Doğal sayılarla çarpma ve bölme işlemlerinin sonuçlarını tahmin eder.

Değer: Sorumluluk

Öğretmen adayı sonuçları tahmin için yuvarlama stratejisinden hareket ederek kartondan bir yol yapıp üstüne 1-2-3-4-5-6-7-8-9 rakamlarını renkli kartonlarla yazdı. Kazanım 5. sınıfa hitap ettiği için görsel materyal öğrencilerin ilgisini çeksin diye rakamlara göz, ayak yaptı. 1-2-3-4 rakamlarının arasına kesik çizgilerden oluşan bir yol, 5-6-7-8-9 arasına dalgalı çizgilerden oluşan bir yol yaptı. Yola yerleştirdiği bir arabanın üzerine rakamları koydu ve koyduğu rakamı öğrencinin yuvarlamasını istedi, böylece öğrencinin en yakın onluğa ulaşmasını sağladı. Rakam 1-2-3-4 ile bitiyorsa kesik çizgili yola, 5-6-7-8-9 ile bitiyorsa dalgalı çizgili yola arabayı yerleştirmek gerektiğini söyledi. Bu süreçte televizyonda gördüğü bir kamu spotundan esinlenerek arabayı ambulansa çevirmeyi ve öğrencilere ambulansa yol verme, onun peşine takılıp arkasından hızlıca ilerlememe fikrinden hareketle sorumlu davranma/ sorumluluk değerini vermeye çalıştı. Böylece hem ambulansla rakamları yuvarlatma hem de ona yol verme fikrinden hareketle sorumluluk değerini verme çalışması yaptı.

Kazanım: M.5.2.1.5. Bir doğruya üzerindeki veya dışındaki bir noktadan dikme çizer. 
Değer: Sayg1

Öğretmen adayı dart oyunundan yola çıkarak dikme çizme fikrini vermeye çalıştı. Öğrencilerin tahtaya asılan bir dart tahtasına oklar atmalarını istedi, okun dart üzerindeki nokta ile oluşturduğu açıdan yola çıkarak dikme kavramını vermeye başladı. Öğrencilerin kendi aralarında konuşarak tahtaya çıkıp ok atacak kişiyi belirlemelerini istedi. Çok fazla sayıda öğrenci tahtaya çıkmak isteyince öğretmen adayı öğrencilere "Siz birbirinize saygılı olarak kimin tahtaya çıkacağını belirleyeceksiniz. Saygılı olun ve kimin çıkacağına siz karar verin" dedi. Öğrencilerin belirlediği kişi tahtaya çıkınca da darta ok attırıp ona dikme çizmeyi öğretti.

Kazanım: M.7.2.1.3. Sayı örüntülerinin kuralını harfle ifade eder, kuralı harfle ifade edilen örüntünün istenilen terimini bulur.

Değer: Vatanseverlik

Öğretmen adayı kendi öğrencilik yıllarını düşünerek o yaşlarda en çok neyi yapmayı sevdiğini düşünmüş ve en çok sek sek oyunu oynadıklarını hatırlamış. Sek sek oyunu aracılığı ile öğrencilere örüntü bilgisini kazandırabileceğini, bu oyuna bir de vatan sevgisi değerini ekleyebileceğini düşünmüş. Kendisi gibi vatanını çok seven gerekirse canını bile vermekten çekinmeyen öğrencileri olmasını istemiş ve bu değeri seçmiş. Küçük yaşlarda bu değerin verilmesinin daha etkili olacağını düşünmüş. Uzun kenarı $5 \mathrm{~m}$, kısa kenarı $3 \mathrm{~m}$ uzunluğunda büyük bir kumaş parçasına her biri $30 \mathrm{~cm}$ 'lik kare kutular çizerek sek sek oyununun temelini oluşturdu. Sek sekte kare kutuların üzerine rakamlar yazdı. 4.-7.-9.-12. ve 15. terimi kendisi yazdı, diğer kutuları boş bırakarak örüntü kuralına göre gelmesi gereken rakamı öğrencilerin bulmasını istedi. Farklı örüntü kurallarını önceden hazırlayarak bir kutuya koydu, öğrencilerin kutudan bir kural çekmesini, okumasını ve yüksek sesle açıklamasını, verilmeyen terimi bulmasını istedi. Öğrencilerin bulması gereken terimin olduğu satırın başına içine taş doldurduğu su şişeleri yerleştirdi, üzerlerine Türk bayrağı yerleştirdi ve şişelerin üzerine de vatan sevgisi ile ilgili sözler yazdı. Kartondan yaptığı bir zarı sek sek kumaşına çıkardığı öğrencilere attırdı, gelen rakama uygun olan terimin bulunmasını, bulduğu terimin daha önceden hazırladığı kartonlardan seçilmesini ve sek sek kumaşının üzerindeki boşluğu kapatmasını istedi. Sınıfı 6 kişilik gruplara ayırarak her bir gruba isim verdi, gruplardan gelen öğrencilere kutudan, örüntü kuralının yazılı olduğu kâğıdı çektirdi, kuralı okuyup anlamalarını, verilmeyen terimi bulursa +1 puan kazanacaklarını, bilemezlerse -1 puan kazanacaklarını söyledi. Verilmeyen terimi bulan öğrenci terimin olduğu satırdaki bayraklı şi- 
şeye gitti, şişenin içindeki bayrağı havaya kaldırdı ve şişenin üzerindeki sözü okudu. Sözün okunması ile diğer öğrenciler alkışlamaya başladılar. Bu şekilde süren oyunda en yüksek puanı toplayan grup ödül kazandı.

Kazanım: M.6.1.7.1. Çoklukları karşılaştırmada oran kullanır ve oranı farklı biçimlerde gösterir.

\section{Değer: Vatansevgisi}

Öğretmen adayı boş su şişelerinin içine farklı renklerde sıvılar koydu. Sıvıların bir şişeden diğerine aktarılmasını sağlayacak bir düzenek oluşturdu, şişelerin üzerine de oranı görmemizi sağlayacak renkli çizgiler çizdi. Şişelerin üzerine kurduğu düzenekte küçük bir boru vardı, bu boruya üfleyince bir şişedeki su diğer şişeye akıyordu ve şişenin içindeki su miktarı değişiyordu. Öğretmen adayı boruyu üfledi, değişen su miktarını öğrencinin söylemesini istedi. Öğrencinin söylediği oran doğru ise öğretmen bu cümleyi onayladıktan sonra, öğrenci, öğretmen masasının üzerinde duran ve üzerinde oranlar yazılı olan kartlardan söylediği oranı buldu ve tahtadaki kartonda kendi yerine yerleştirdi. Şişede görülen oranlar değiştikçe söylenen oranlar da değişti ve söylenenler tahtaya yapıştıkça Anıtkabir puzzel'ı tamamlandı. Anıtkabir ve Atatürk hakkında konuşmaya başlayan öğretmen adayı öğrencilere vatan sevgisini aşılamaya çalıştı.

Kazanım: M.7.2.2.1. Eşitliğin korunumu ilkesini anlar.

Değer: Eşitlik

Öğretmen adayı tahterevalli üzerinde bazı eşyaları tartarak eşitlik fikrini vermeye çalıştı. Bunun için tahtadan tahterevalli kestirmiş, orta noktasını ayarlamış ve dengeyi sağlamış. Tahterevallinin uç kısımlarına plastik bardak yapıştırarak içine bir şeyler konulabilir hale getirmiş. Bardakların içine koymak için plastik 2 bebek, 100'er gramlık 2 poşet şeker, bilyeler, zar, mumdan kesilmiş $\mathrm{X}$ şekli, kuş şeklinde 2 tane tuzluk, oyuncak ayılar, süs biberonlar getirmiş. Hazırladığı bu düzenekle ve getirdiği araçlarla öğrencilere eşitliğin korunumu fikrini vermeye çalıştı. Öğrencileri tahtaya kaldırdı, tahterevallinin üzerine aynı olan ağırlıkları yerleştirtti ve eşitliğin korunumunu fark ettirdi. Tahterevallinin üzerine aynı ağırlıkları yerleştiren öğrencilere kavanozdan bir oyuncak yumurta kutusu çektirdi, yumurta kutusunun içinde sevgi cümleleri yazan küçük kâğıtlar vard1, öğrencilere bu sözcükleri yüksek sesle okuttu.

5) "Öğretmen adaylarının değer seçme, bu değeri kazanıma uygun olarak sunma, kazanım ve değere uygun materyal geliştirme, geliştirdiği materyali sınıfta sunma sürecinde hissettikleri duygular nelerdir?" sorusuna yanıt vermek için öğretmen adaylarının günlükleri analiz edilmiştir. 
Öğretmen adaylarının bu süreçte; üzüntü, stres, korku, mutluluk, çöküntü, tedirginlik, heyecan, yorgunluk ve hayal kırıklığı duygularını hissettikleri görülmüştür. Öğretmen adaylarının hissettikleri duyguların sayısal analizi verilmemiştir. Çünkü öğretmen adayları aynı anda birden fazla duyguyu hissettiklerini belirtmişlerdir. Mutluluk ve heyecan, stres ve korku, korku ve tedirginlik, çöküntü ve yorgunluk birbirine eşlik eden duygulardandır. Öğretmen adaylarının duyguları olumlu ve olumsuz olarak iki kategori altında toplanmıştır. Olumlu kategorisindeki duyguların hepsi aşağıda sıralanmıştır:

"Kazanımı anladım, bu kazanıma uygun materyal hazırlamak ve bu materyali değer ile bütünleştirmek zor değil, kolayca başarabileceğime inanıyorum. Ayrıca küçük sınıflara yönelik bir kazanım olduğu için eğlenceli sunabileceğime inaniyorum. Mutluyum"

"İlk kez materyal geliştireceğim ve değerle ilgili bir çalışma yapacağım. Çok heyecanliyım."

"Zor değil başarırım."

"Bu derste yapacağım sunum ve geliştireceğim materyal sayesinde acaba nasıl bir öğretmen olacağım sorusuna yanıt bulacağımı düşünüyorum Mutluyum. Kazanımım zor ama zaman harcayarak yapacağımı düşünüyorum.”

Olumsuz kategorisine giren duyguları hisseden öğretmen adaylarının duygularının bazıları aşağıda sıralanmıştır:

"Bu derse her girişimde yeni bir şey öğrenip şok oluyorum. Başıma daha neler gelecek acaba, çok tedirginim."

"Kazanımı okuyorum, anlamıyorum. Ne yapacağımı bilemiyorum. Kazanım zor, materyal hazırlamak daha zor, materyali hazırlarken içindeki değeri fark ettirmek çok daha zor. Kendime olan inancım bitti, enkaz gibiyim.”

"Sunum planına göre ilk sunumu ben yapacağım. Şoktayım, midem bulanıyor. Ağlayarak sınıftan kaçmak istiyorum.”

"Önce korkmuştum, işin içine girince daraldım."

"Materyal hazırlamada sorun yok yaparım ama programda yer alan değerlere henüz ben bile sahip değilken bu değerlerin öğretimini yapmam nasıl istenir benden, anlamiyorum?"

"Kazanımım bölme işlemi ile kesir kavramını ilişkilendirmek ile ilgili. Nasıl anlatacağımı bilmiyorum, buna göre materyal geliştirmeyi de bilmiyorum, değer eklemeyi hiç hiç bilmiyorum. Çok gerildim”. 
"En zor kazanım bana gelmiş, ne yapacağımı bilmiyorum."

“Kazanım materyal geliştirmek için çok zor, kazanımın 8. sınıf olması da zor. Her şey beni buluyor zaten"

"Biz daha ikinci sınıf öğrencisiyiz. Bu işlerle uğraşmak için çok küçüğüz. Keşke dördüncü sınıfta yapsak bu işleri. Çok bunaldım”.

\section{Tartışma, Sonuç ve Öneriler}

Araştırma sonunda matematik dersi öğretmen adaylarının "matematik dersinde değerler eğitimi”'ne yönelik görüşlerinin olumlu olduğu görülmüştür. Bishop'un (1999) matematiğin değer içermediği yönündeki yaygın inanç nedeniyle bu konunun ihmal edildiğini belirtmesine rağmen çalışma grubunda yer alan öğretmen adaylarının çoğunluğunun matematik dersinde değerler eğitimini yapılabileceğini düşünmesi sevindiricidir. Ancak matematik dersinde değerler eğitiminin bazı kazanımlarla yapılabileceğini bazıları ile yapılamayacağını belirten öğretmen adaylarının oranı da az değildir (\%32). Bu konuda öğrencilerin daha yaratıcı düşünmelerini sağlayacak eğitim programları ya da etkinlik örnekleri hazırlanabilir.

Araştırma sonunda matematik dersi öğretmen adaylarının "matematik kazanımlarına uygun materyaller aracılığı ile değerler eğitimi”ne yönelik görüşlerinin olumlu olduğu görülmüştür. Çalışma grubunda yer alan öğretmen adaylarının yarısından fazlası uygun materyaller aracılığı ile değer eğitiminin gerçekleştirilebileceğini düşünmektedir. Matematik dersinde değerler eğitiminin bazı materyallerle yapılabileceğini bazıları ile yapılamayacağını, bunun yanında materyaller aracılığı ile değer eğitimi yapılamayacağını düşünen öğretmen adayı oranı da oldukça düşüktür. Bu konuda öğrencilerin daha yaratıcı düşünmelerini sağlayacak eğitim programları ya da etkinlik örnekleri hazırlanabilir.

Matematik dersi öğretmen adaylarının değerlere yükledikleri anlam ile bu değerlerin sözlük tanımları arasındaki uyumun oldukça düşük olduğu görülmüştür. Bu durum çalışmaya katılan öğretmen adaylarının değer tanımlarını ya da değerlere yükledikleri anlamın doğru olmadığını, öğretmen adaylarının bu konuda bilgi ve alg1 eksiklikleri olduğunu göstermektedir. Öğretmen adaylarının bilgi eksikliği varken ya da değerlere yükledikleri anlam doğru değilken bunu öğrencilere aktarmaları doğru olmayacaktır. Bu araştırmada öğretmen adaylarının kimisi vatanseverlik değerini "vatan için canını vermek" şeklinde tanımlamışken, kimisi "ülkem için çok çalışmak” olarak tanımlamıştır. Vatan 
için canını vermek ve çok çalışmak arasındaki anlam oldukça farklıdır. Tanımı bu şekilde farklı yapan öğretmen adaylarının öğretecekleri değerler de farklı olacaktır. Her öğretmen kendi algısına göre değişen derecede değer öğretimi yapacaktır. Bu kapsamda Millî Eğitim Bakanlığı tarafından değerlerin çerçevesinin belirlenmesi yararlı olacaktır. Akbaş'ın $(2008,13)$ Simon, Leland ve Kirschenbaum (1972)'dan yaptığı alıntıda da belirttiği gibi gençlerin hayatlarını nasıl yaşayacakları, seçimlerinde ve karar almalarında nasıl davranacaklarını belirlemeleri, karşılaştıkları soruların yanıtlarını doğru verebilmeleri için kendi değerlerini açıklığa kavuşturmaları gerekmektedir, bu nedenle gençlere ve öğretmen adaylarına bu konuda yardım edilmelidir.

Araştırma bulgularında öğretmen adaylarının sevgi ve vatanseverlik değerini önemsedikleri ortaya çıkmıştır. Bu durum Karaduman, Çengelci-Köse ve Eryılmaz (2017) tarafından yapılan araştırmanın bulguları ile de örtüşmektedir. Adı geçen çalışmada bir devlet üniversitesinde Eğitim Fakültesi'nde Sosyal Bilgiler Öğretmenliği programına devam eden öğretmen adaylarının sosyal medyada yansıttıklarını düşündükleri değerler belirlenmeye çalışılmıştır. Öğretmen adayları sosyal medyada sırasıyla dayanışma, saygı, yardımseverlik, duyarlılık ve sevgi değerini yansıttıklarını belirtmişlerdir.

Yiğittir (2010) tarafından yapılan bir çalışmanın bulguları çocuğu ilköğretim kademesine devam etmekte olan velilerin okullarda sırasıyla; aile birliğine önem verme, çalışkanlık, Bayrağa ve İstiklal Marşı'na saygı, vatanseverlik, sorumluluk, dürüstlük, doğruluk, vb. değerlerin öğretimini tercih ettiklerini ortaya çıkarmıştır. Matematik dersi öğretmen adaylarının öğretimini tercih ettikleri değerin vatanseverlik olması, velilerin beklentileri ile örtüşmektedir. Öğretmen adaylarının değeri seçme gerekçeleri ayrıntılı çalışmalarla belirlenmelidir. Ülkenin toplumsal, kültürel, ekonomik yapısı, bireylerin özel yaşamlarındaki durumlar, çalışmanın yapıldığı dönemde ülkenin vatandaşlarını etkileyen olaylar gibi pek çok faktörün bu süreçte etkin olacağı düşünülebilir.

Öğretmen adaylarının öğretimini en çok tercih ettikleri değer "sevgi"dir. Bu bulgu Başçı- Namlı (2017) tarafından yapılan araştırmanın bulgusu ile; “Öğretmenlere göre öğrencilere kazandırılması gereken en önemli değerler; dürüstlük, sayg1 ve sorumluluk, sevgi, çalışkanlık." ile örtüşmektedir. Ancak öğretmen adaylarının "sevgi" değerinin tanımını bilme durumuna bakıldığında tanımın öğretmen adayları tarafından iyi bilinmediği görülmektedir. Diğer bir ifade ile öğretmen adaylarının sevgi değerine yükledikleri anlam ile sevgi değerinin sözlüklerde yer alan anlamının uyumu (16/128) oldukça düşüktür. Öğretmen aday- 
larının anlamını yanlış bildikleri diğer bir ifade ile yanlış anlam yükledikleri bir değeri öğrencilere öğretmeye çalışmaları olumsuz sonuçlar doğurabilecektir. $\mathrm{Bu}$ bulgu değerlerin öğretiminde Millî Eğitim Bakanlığı tarafından oluşturulacak çerçevenin önemini bir kez daha ortaya koymaktadır.

Öğretmen adaylarının matematik kazanımlarına uygun materyaller aracılı̆̆ 1 ile "değerler eğitimi"ne yönelik görüşlerinin olumlu ancak değer ve kazanıma uygun materyal hazırlama, sunma ile ilgili duygularının ağılıklı olarak olumsuz olduğu görülmüştür. Bu olumsuz duyguların gerekçesini ve kaynaklarını ortaya çıkaran araştırmaların yapılması önerilmektedir.

\section{Kaynakça}

Akbaş, O. (2004). Türk milli eğitim sisteminin duyuşsal amaçlarının ilköğretim ii. Kademedeki gerçekleşme derecesinin değerlendirilmesi. Yayınlanmamış doktora tezi, Gazi Üniversitesi, Ankara.

Akbaş, O. (2008). Değerler eğitimi akımlarına genel bakış. Değerler Ĕğitimi Dergisi, 6(16), 9-27.

Bacanlı, H. (2006). Duyuşsal davranış eğitimi. (3. Baskı). Ankara: Nobel Yayın Dağıtım.

Balcı, F. A. ve Yelken, T. Y. (2013). İlköğretim sosyal bilgiler programında yer alan değerler ve değer eğitimi uygulamaları konusunda öğretmen görüşleri. Ahi Evran Üniversitesi Kırşehir Eğitim Fakültesi Dergisi, 14(1).

Başç1-Namlı, Z. (2017). Sınıf öğretmenlerinin perspektifinden değerler eğitiminin incelenmesi: Erzurum örneği. İnsan Ve Toplum Bilimleri Araştırmalarl Dergisi, 6(1), 343-367.

Berkowitz, M. W. (2011). What works in value educations. International Journal of Educational Research, 50, 153-158.

Bishop, A. J. (1999). Mathematics teaching and values education-an intersection in need of research. ZDM Mathematics Education, 31(1), 1-4.

Bishop, A. J. (2012). From cultureto well-being: a partial story of values in mathematics education. ZDM Mathematics Education, 44(1), 3-8.

Dede, Y. (2006). Lise matematik ders kitaplarında taşınan matematiksel değerler. Kuram Ve Uygulamada Eğitim Bilimleri, 6(1), 81-132.

Dede, Y. (2007). Matematik öğretiminde değerlerin yeri. Abant İzzet Baysal Üniversitesi Eğitim Fakültesi Dergisi, 7(1), 12-25.

Dil Derneği. Türkçe sözlük: http://www.dildernegi.org.tr/TR,274/turkce-sozluk-ara-bul.html Erişim: 25 Haziran 2018 
Dilmaç, B. (2002). Insanca değerler eğitimi. Ankara: Nobel Yayınevi.

Dilmaç, B. (2011, Ekim). Değer öğretim yaklaşımları. Değerler eğitimi sempozyumu'nda sunulan bildiri, Osmangazi Üniversitesi, Eskişehir.

Dökmen, Ü. (2000). Evrenle uyuşma sürecinde varolmak, gelişmek ve uzlaşmak. İstanbul: Sistem Yayınları.

Durmuş, S. (2010). Matematik eğitiminde değerler üzerine bir deneme. Değerler Ë̆itimi Dergisi, 8(20), 65-79.

Elbir, B. ve Bağcı, C. (2013). Değerler eğitimi üzerine yapılmış lisansüstü düzeyindeki çalışmaların değerlendirilmesi. Turkish Studies, 8(1), 13211333.

Ernest, P (2016). Mathematics and values. In: Larvor B. (Edt). Mathematics Cultures. Trends In The History Of Science. Birkhauser, Cham. https:// doi.org/10.1007/978-3-319-28582-5_12.

İdi-Tulumcu F. ve Tulumcu, M. F. (2015). İlköğretim ikinci kademe Türkçe ders, programlarında yer alan değerler. Değerler Ĕ̈itimi Dergisi, 13(29), 535-560.

Karaduman, H., Çengelci-Köse, T. ve Eryılmaz, Ö. (2017). Sosyal bilgiler öğretmen adaylarına göre sosyal medyada değerler. Turkish Online Journal of Qualitative Inquiry (TOJQI), 8(2), 250-271.

Karasu-Avc1, E. ve Ketenoğlu-Kayabaşı, Z. E. (2018). Hayat bilgisi dersi öğretim programlarının amaçlarındaki değerlerin içerik analizi (1936-2018). Değerler Eğitimi Dergisi, 35, 16.

Keskin, S. C. ve Keskin, Y. (2009). Cumhuriyet dönemi ilkokul (Ilköğretim 1. kademe) sosyal bilgiler ve onun kapsamına giren ders programlarında bir değer olarak "barış"1n yeri. Değerler Eğitimi Dergisi, 7(17), 69-92.

Kurtdede-Fidan, N. (2009). Öğretmen adaylarının değer öğretimine ilişkin görüşleri. Kuramsal Eğitimbilim Dergisi, 2(2), 1-18.

Öncül, R. (2000). Eğitim ve eğitim bilimleri sözlüğü. İstanbul: Milli Eğitim Bakanlığı Yayınları.

Selvitopu, A., Taş, A. ve Bora, V. (2015). Parents' expectations about values to be taught to their children at secondary schools. Kastamonu Education Journal, 23(3), 979-994.

Sönmez, V. (2010). Program geliştirmede ögretmen el kitabl. Ankara: An1 Yayıncilik.

Türk Dil Kurumu. TC Başbakanlık Atatürk Kültür Dil ve Tarih Yüksek Kurumu. Web: www.tdk.gov.tr 
Tapsir, R., Pa, N. A. N. ve Zamri, S. N. A. B. S. (2018). Reliability and validity of the instrument measuring values in mathematics classrooms. Malaysian Online Journal of Educational Sciences, 6(2), 37-47.

Thornberg, R. (2008). The lack of professional knowledge in values education. Teaching and Teacher Education, 24(7), 1791-1798.

Thornberg, R. ve Oğuz, E. (2013). Teachers' views on values education: A qualitative study in Sweden And Turkey, International Journal of Educational Research, 59, 49-56.

Yıldırım, T. (2017). Yeni ortaöğretim tarih ders programları ve 9. Sinıf tarih ders kitabında değerler eğitimi. Turkish Studies, 12(33), 557-572.

Yıldırım, A. ve Şimşek, H. (2011). Sosyal bilimlerde nitel araştırma yöntemleri. Ankara: Şeçkin.

Yiğittir, S. (2010). İlköğretim öğrenci velilerinin okullarda kazandırılmasını arzuladığı değerler. Değerler Ĕ̆itimi Dergisi, 8(19), 207-223. 
Extended Abstract

\section{The Relationship Between the Materials Prepared by Prospective Primary School Mathematics Teachers with Values Set Out in the Curriculum}

Dilşat PEKER ÜNAL, Corresponding Author. Assistant Professor.

Yozgat Bozok University, Faculty of Education.

E-mail: dilsat.unal@bozok.edu.tr

ORGID: 0000-0002-1370-4950

Emine Özgür ŞEN, Assistant Professor.

Yozgat Bozok University, Faculty of Education, Mathematics.

E-mail: senozgur@yahoo.com

ORCID: 0000-0002-8177-0984

\section{Introduction}

There are many elements that shape and guide individuals' behaviours. Some of these elements include; knowledge and culture accumulation of the past, traditions and customs, the characteristics of the society in which the individual lives, the rules adopted by society, behaviours displayed when the rules are not obeyed and the values keeping the society together. Values from these listed elements; shape the social life (Dökmen, 2000), they secure that individuals with different properties obey the rules that are accepted by everybody and thus meet on common ground, they facilitate agreement and living together and they tell individuals what is important in social structure, what should be chosen and how individuals should live (Akbaş, 2008). Values education begins at home and continues in educational institutions. The values education given in educa- 
tional institutions, in addition to increasing the academic success of children, allows them to exhibit behaviors that are accepted by everyone and that promote ethical and social interests (Berkowitz, 2011).

Approaches teachers adopt and behaviours they display in the classroom are important in instilling values in students. Approaches used in teaching values can be listed as; direct teaching of values, concretising the values, value analysis, holistic approach, implicit curriculum and character education (Dilmaç, 2011). Whatever the approach a teacher employs a teacher should be active in the process of values education. Kurtdede-Fidan (2010) conclude that prospective teachers attribute different meanings to values and that lecturers are inadequate in teaching the values. In a study in which M.A theses on values education are examined, Elbir and Bağc1 (2013) conclude that values education in Turkey has not adequately been internalised. In another study conducted with the participation of secondary school students' parents, it was found that parents support the idea that humanistic, nationalistic and moral values should be acquired at school, while schools fall short of the expectation in instilling values in students (Seviloğlu, Bora and Taş, 2014). Studies conducted have demonstrated that the issue of values education is not attached enough importance, that teachers are inadequate in setting a model about values education and that parents find the process of instilling values inadequate. The findings listed above indicate that further studies should be made concerning the issue of values education along with teachers' role. The mathematics lesson is known as an abstract-technical field dealing with numbers and shapes, and therefore it is thought to be far from the subjects that touch emotions such as values. Dede (2006) stated that mathematics contained various values, yet these values are taught implicitly and not explicitly, and that coursebooks of mathematics contained mathematical values such as rationality, control and clarity, whereas mathematical education include values such as formal look, theoretical knowledge, procedural learning, comprehension, accessibility and evaluation. Thus, it is evident that mathematics course also includes various values.

Values are available in many courses including mathematics, and they need to be given to students by teachers making use of various approaches. Teachers' interest in and their attitudes towards values are important in getting students acquire values. This paper aims to determine the prospective teachers' views on the values included in the mathematics curriculum (justice, friendship, honesty, self-control, patience, respect, love, responsibility, patriotism, benevolence). 
The general purpose of this study is to determine the views about the process of values teaching in the mathematics course and to learn about the products the prospective teachers put forward in order to teach values in mathematics course. Within the scope of this general purpose, the following questions are asked:

1) What are the views held by prospective secondary school mathematics teachers regarding "values education in mathematics course" and "values education through material design"?

2) Are the definitions of the root values included in the mathematics curriculum consistent with the definitions adopted by prospective teachers?

3) Which value do the prospective teachers prefer to give in the scope of instructional technologies and material design course?

4) What concrete products emerge when the prospective teachers carry the material development process along with the process of values education?

5) What do the prospective teachers feel when they carry the material development process and values education process together?

\section{Method}

Events were monitored in their natural environment, and therefore qualitative research methods were used in this study. Such techniques as interview and literature review were used to determine the participants' perceptions about the root values available in the mathematics curriculum and to evaluate the materials they had prepared on the basis of their perceptions. The data were then put to content analysis.

The study group was composed of 56 prospective teachers who attended the Mathematics section of the Department of Mathematics and Science Education of Yozgat Bozok University, and who were second-year students and who had taken the Instructional Technologies and Material Design course.

The prospective teachers were given structured interview form containing the following sentences

"Values education in mathematics course .......... because ........" and

"values education through material design ............ because ........."

And they were asked to fill in the first gaps in the sentences by using "can be performed" or "cannot be performed" and to explain their reasons in the blanks starting with "because". 
The participants were asked to define the root values available in the mathematics curriculum (justice, honesty, friendship, self-control, patience, respect, love, responsibility, patriotism and benevolence) so that we can find answers to the second research question.

They also were asked to keep a diary throughout the course Instructional Technologies and Material Design (for 14 weeks) to find answers to the remaining research questions.

The research data were collected within the scope of the course Instructional Technologies and Material Design- which was taught by one of the authors. Then the data were put to content analysis.

\section{Discussion, Gonclusion and Recommendations}

In consequence, it was found that the prospective mathematics teachers had positive views about "values education in mathematics course". A considerable percentage of prospective teachers $(32 \%)$ stated that values education could be done with some gains and that it could not be done with some others. Educational programmes or sample activities can be prepared to make students think in a more creative way in this matter.

It was found consequently that prospective mathematics teachers had positive views about values education through materials suitable to mathematical acquisition. More than half of the prospective teachers in the study group thought that values education could be performed with suitable materials. The rate of those thinking that values education in mathematics course could be done with some materials but cannot be done with others and the rate of those who did not think that it could not be done was quite low. Educational programmes or sample activities can be prepared to make students think in a more creative way in this matter.

The consistency between the meanings prospective mathematics teachers attributed to the values and the values' dictionary definitions was found to be very low. This situation indicates that the participants' definitions of the values or the meanings they attribute to the values are incorrect and that they have inadequate knowledge or perception. When teachers are lacking in knowledge or they attribute incorrect meanings to the values, they will certainly be unable to transfer correct knowledge to students. Some of the participants defined the value of patriotism as "sacrificing oneself for the nation" while some others defined it 
as "working hard for the good of the nation". There is considerable difference between the two meanings. Thus, what they will teach will also be different. The degree of values teaching will change according to each teacher' perception. In this context, it would be useful for the Ministry of National Education to determine the framework for the values. As Akbaş $(2008,13)$ states quoting from Simon, Leland and Kirschenbaum (1972), the youth should clarify their own values so that they can determine the way they will lead their life and how they will act in making their choices and decisions and so that they can find correct answers to the questions they will encounter in their life. Therefore, young people need to be helped in this matter.

The findings obtained here revealed that the prospective teachers considered the values of love and patriotism important. This finding is in parallel to the one obtained in Çengelci, Köse and Eryılmaz (2017). The aforementioned study makes an attempt at determining the values of prospective social studies teachers, who study in Educational Faculty of a state university, display on the social media. It was stated that the prospective teachers displayed values of solidarity, respect, benevolence, sensitivity and love to the social media respectively.

The findings obtained in Yiğittir (2010) demonstrated that the parents whose children were the elementary school students preferred the teaching of values such as; attaching importance to parent-teacher association, studiousness, respect for the flag and the national anthem, patriotism, responsibility, honesty, righteousness, respectively. The fact that the prospective mathematics teachers preferred the teaching of the value of patriotism parallels parents' expectations. The justifications for prospective teachers' preference for a value should be determined in further studies. It could be argued, that several factors such as the existing social, cultural, economic environment of a country, the situations the individuals encounter in their personal life during the period the study is conducted, are factors affecting the study participants.

The most preferred value for prospective teachers is; "love". This finding parallels the one obtained in Başç1-Namlı (2017)- which states that "according to teachers, the most important values that should be given to students are honesty, respect and responsibility, love, studiousness...". However, upon examining how well the prospective teachers knew the definition of the value of love, it was found that they did not know the definition very well. In other words, the consistency between the meanings prospective teachers attributed to the value of love and the meaning given in dictionaries was low (16/128). Teaching the 
values whose meanings the prospective teachers knew incorrectly to students will yield negative results. This finding manifests the need of setting a framework related to value education by the Ministry of National Education.

It was found that the prospective teachers had positive views about values education through materials suitable to mathematics acquisition, yet, they had negative views and feelings about preparing suitable materials and presenting them. It is recommended that further studies to be carried out to unveil the reasons behind these negative views and feelings. 